Aletria, Belo Horizonte, v. 29, n. 4, p. 113-128, 2019

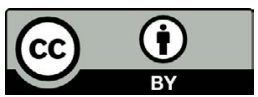

\title{
The Lists of Paradise Regained: An Economy of the Full and the Empty
}

\author{
As Listas em Paradise Regained: \\ uma economia do cheio e do vazio
}

\section{Luiz Fernando Ferreira Sá}

Universidade Federal de Minas Gerais (UFMG), Belo Horizonte, Minas Gerais / Brasil saluiz18@gmail.com

\begin{abstract}
This article works from Madeleine Jeay's Le Commerce des Mots (2006), Umberto Eco's Infinity of Lists (2009), and Bernard Sève's Philosophie des Listes (2010) to understand the abundance of lists in John Milton's Paradise Regained. The lists in Paradise Regained emerge from the following conditions: the fantasy of chaos remaining an unfulfilled horizon, the complicated coherence among things escaping the worst disorder, and the tortuous cohesive power of analogy barely unifying a worldview by holding the chaos of reality at bay. In sum, the lists in the short epic would mark, as a manifestation, the trace, like the shadow, of the intractable fallen world within the very act of worldliness (much like the creation of an alternative Christian ethos), always leaving a space of nothingness necessarily paradoxical and in some ways astonishingly so.
\end{abstract}

Keywords: Paradise Regained; lists; economy; John Milton.

Resumo: Este artigo parte dos estudos Le commerce des Mots (2006), de Madeleine Jeay, Infinity of Lists, de Umberto Eco (2009), e Philosophie des Listes (2010), de Bernard Sève, para compreender a abundância de listas no Paradise Regained, de John Milton. As listas em Paradise Regained emergem das seguintes condições: a fantasia do caos permanecendo um horizonte não cumprido, a complicada coerência entre as coisas que escapam da pior desordem e o tortuoso poder coesivo da analogia minimamente unificando uma cosmovisão que manteria o caos da realidade sob controle. Em suma, 
as listas no curto poema épico marcariam, por meio de uma manifestação, o traço, como uma sombra, do intratável mundo pós-queda dentro do próprio ato de "mundanização" (muito parecido com a criação de um éthos cristão alternativo), sempre deixando um espaço do nada necessariamente paradoxal e, de certa forma, surpreendente.

Palavras-chave: Paradise Regained; listas; economia; John Milton.

Whereas literature is an ancient enterprise, through which humans seek to understand how reality is constructed by making sense of the world at large, literary criticism serves the purpose of perusing verbal works of art from a wide range of perspectives to find out the claims to truth contained in them about humanity and the world. Many have been the critical stances adopted in relation to John Milton's Paradise Regained, from formalist to biographical and historical criticism to psychological, sociological, mythological, and reader-response approaches that have not been loath to respond to the epic's crucial questionings and theologicophilosophical conundrums. What this means for literary criticism, in general, and for Miltonists of every persuasion, in particular, is that we might come to see our desire for something other than critique as just that - desire, with all of its attendant difficulties and short-comings. Our desires and experiences of reading entail compromises, achievements, responses, failures, strokes of luck, propinquity.

The list may go on in-definitely, but if we concentrate on one of the above items, we may say that the pattern of scholarly response to Paradise Regained is complex and difficult enough to understand, let alone produce a comprehensive study of the critical legacy called forth by the short epic. Curiously enough, the poem simply narrates the attempted seduction of Jesus in the Judean desert, and nothing much happens: the Son of God remains unmoved. Many Miltonists, for example, take the position that the Son is unmoved and rejects Greco-Roman learning not for its own sake, but because Satan presents it as an end in itself and uses it as a method of confusing the Son's higher responsibilities to God the Father. The critical arena associated with this text, however, is in constant mutation and suffers continual shifts because there seem to be questions left unanswered or whose answers are not wholly satisfactory. Laura Knoppers has listed some of the most basic unsettled questions: 
The Son refuses to act or even to show any emotion. Faced with its spare style, austere setting, and paucity of action, readers have found the poem, as well as its hero, baffling and cold. Even the most basic questions remain unsettled. Why this subject? Why not the crucifixion? Is there development? Does the Son learn anything? Is there a miracle atop the temple tower? Why does Satan fall astonished? Such cruxes are not resolved by classifying the poem as brief epic. Why no heroic action, figurative richness, poetic allusiveness, divine intervention? ${ }^{1}$

One point needs clarification here: the lack of figurative richness in the poem is questionable and I propose to shed light on that richness by analyzing the many lists found in the text. One critical and decisive position, nonetheless, remains clear and may be said to be a consensus among Milton scholars, that in Paradise Regained, as in so many of his other works, Milton is exploring God's ways, and the fault-lines within the bible provide a model for this exploration. In the reading I propose here, the short epic counterbalances a conservative typological understanding of patience and fortitude with an acute sense of ironic and subversive practices of interpretation regarding the many lists found in the poem.

This article works from Madeleine Jeay's Le Commerce des Mots (2006), Umberto Eco's Infinity of Lists (2009), and Bernard Sève's Philosophie des Listes $(2010)^{2}$ to understand the abundance of lists in Milton's Paradise Regained. This project begins with the presupposition that lists matter for culture, for art, for philosophy, for literature, and for signification or "mundanization" (our need to understand reality and make sense of the world at large) in general. Lists point towards that which is not present, that which is inarticulate, and that which cannot be expressed or understood in plain descriptive or narrative terms. Lists formed and informed the hybrid Renaissance culture that Milton inherited ${ }^{3}$ and put to use in his major epic poems because they were called to act as artistic devices describing experiences that extended beyond the limits of human

\footnotetext{
${ }^{1}$ KNOPPERS. Paradise Regained and the Politics of Martyrdom, p. 213.

${ }^{2}$ See also the comprehensive publication MILCENT-LAWSON; LECOLLE; MICHEL. Liste et Effet Liste en Littérature.

${ }^{3}$ In relation to the list and Renaissance literature, see Knight (2013), Halpern (1991), and Cave (1979).
} 
language, such as the Fall, the tempter, the redeemer or the regaining of paradise.

It is not surprising that lists are part of the blind spots in literary theory. Questions without immediate answers continue to rage. Can there be a style in the list? To what extent does the list interrupt the narrative/ descriptive process and introduces an alternative fiction? However, there are relatively clear points regarding the use of the list and its effects on literary texts: the list is indebted to an analysis that takes into account its rhizomatic structure. Hence, a plethora of list types (enumerations, series, catalogues, inventories, records, litanies, recitals, accumulations, Rabelaisian accumulations, and so many others) and a myriad of possibilities of reading the list effect; for example, that the lists are a privileged space in literature for a radical questioning of encyclopedic ambition or for an ironic challenge to what Edgar Allan Poe's Seneca phrased as "nothing is more hateful to wisdom than excessive cleverness". Whatever the case, lists break with discursiveness to reactivate the semantic virtualities and invite us to a well-informed reading that proceeds by connections and disconnections or reconnections of every sort. In short, when they appear in poetic narratives and/or descriptions, lists seem to challenge the syntax and give freedom to words.

Some generalizations about the lists seem true: every list strives to conjure up the "volume" of the world or the list is fundamentally under tension, divided between the ordering of the now and the lack of order of the future, even the view that the list succeeds in presenting virtualities. Thus, it is often clear the tendency of lists, in literature, to trigger an almost automatically reactive response to texts in "comic" endeavors of sabotage and parody of all institutionalized knowledge or authority. In addition, the list proposes a renewed content in calling us to see anew a certain thing or a state of things, for it does not presuppose any previous synthesis but takes form in the process of constant updating. A sensitive and perceptive reader seems to grasp a reality that is not given, but whose characteristics gradually emerge in and between the lists.

What is perhaps noteworthy about my ensuing emphasis on the maximalism of the list effects in the short epic is that it runs side by side with the familiar premise that Paradise Regained depends on the stoking of the passions. The interest of this poem lies significantly in visualization, but its pictorial highpoints are distinctly list-oriented: 
upticks in signification rather than occasions for intense emotional engagement. The two first lists of Book I concentrate on the special relation between Father and Son: the opening one is about knowledge and protection, registering verbs associated with actions contrary to them ("The Father knows the Son; therefore secure/ Ventures his filial virtue, though untried, / Against whate'er may tempt, whate'er seduce, / Allure, or terrify, or undermine"). ${ }^{4}$ The second occurrence is of lexical repetition and accumulation, a complex play on pronouns pointing to Father and Son being coterminous ("Straight knew me, and with loudest voice proclaimed / Me him [for it was shown him so from Heaven], / Me him whose harbinger he was; and first / Refused on me his baptism to confer $[\ldots]$ / The Spirit descended on me like a dove, / And last, the sum of all, my Father's voice, / Audibly heard from Heaven, pronounced me his, / Me his beloved Son [...]"). ${ }^{5}$

In direct contrast to those initial, safeguarding lists, the following lexical accumulations in Book I are directed at Satan and his cohorts. Whereas Satan dwells copartner with humans in the world, aiding and advising them with presages, signs, answers, oracles, portents and dreams, ${ }^{6}$ his condition as a poor, miserable captive results from his being deposed, ejected, emptied, gazed, unpitied, shunned, and turned into " $\mathrm{A}$ spectacle of ruin and of scorn". 7 To clarify Satan's fallen status further, a list of verbs is provided as the means by which he rules some regions of the world: to lie, to say and unsay, to feign, to flatter, to abjure. ${ }^{8}$

On the one hand, there is the temptation of totality in the two first lists of Book I (the inventory-list as a census of properties ending as "the sum of all") and, on the other hand, the protest against monumentality (including an almost imperceptible homogeneity) of form and structure, for Satan is listed to be soon after defined as a spectacle of ruin and scorn; between encyclopedic ambition and the conjuration of any system, there is also the perplexing activism represented by the lists to be soon directed at and mouthed by Satan. Here we come across a beautiful, phenomenological description of the list: this tangency (temptation

\footnotetext{
${ }^{4}$ The references to Paradise regained are to book and line number: Book I, 176-179. 5 MILTON. Paradise Lost and Paradise Regained. Book I, 273-285.

${ }^{6}$ MILTON. Paradise Lost and Paradise Regained. Book I, 391-386.

${ }^{7}$ MILTON. Paradise Lost and Paradise Regained. Book I, 415.

${ }^{8}$ MILTON. Paradise Lost and Paradise Regained. Book I, 472-474.
} 
of totality and protest against monumentality) indicates very well the manner of coordination proper to those lists. And yet, the list is one of the ways to revitalize language: an active principle that loosens the bonds of discourse and evokes the bondage of concatenations, always-already calling attention to the injunction of meaning. The list may proceed with a "de-grammaticalization" of a petrified speech in its repetitive montages or it may proceed by "decontextualization": in this, it is close to textual collage. First and foremost, the list has an organizing function, it responds to the instinct of order inherent to the human mind. The list, sometimes chaotic and disjunctive, simulates, through its expansion and its volume of space, an encyclopedic saturation, the writing of memories or of taxonomic inventories, and it also responds immediately to the ambition of language to structure reality.

Book II of Paradise Regained presents us with a montage and a collage-like list of superlatives connected to Belial in comparison to Asmodai, of some female beauties of classical antiquity, and of adored names in ancient Greece and Rome. ${ }^{9}$ Carried on to the second list of Book II by the superlative "exquisitest", we now see "A table richly spread, in regal mode" ${ }^{10}$ with dishes, meats, pastry, fish, served by stripling youths, by nymphs and damsels from classical antiquity or from old fables. ${ }^{11}$ The

\footnotetext{
${ }^{9}$ The complete list as follows: Belial, the dissolutest spirit that fell, / The sensualest, and after Asmodai / The fleshliest incubus, and thus advised [...]/ Such object hath the power to soften and tame / Severest temper, smooth the rugged'st brow, /Enerve, and with voluptuous hope dissolve, / Draw out with credulous desire, and lead / At will the manliest, resolutest breast, / As the magnetic hardest iron draws [...] / Some beauty rare, Callisto, Clymene, / Daphne, or Semele, Antiopa, / Or Amymone, Syrinx, many more / Too long, then lay'st thy scapes on names adored, / Apollo, Neptune, Jupiter, or Pan, / Satyr, or Faun, or Sylvan? (MILTON. Paradise Lost and Paradise Regained. Book II, 150-191).

${ }^{10}$ MILTON. Paradise Lost and Paradise Regained. Book II, 340.

11 The complete list as follows: With dishes piled, and meats of noblest sort / And savor, beasts of chase, or fowl of game, / In pastry built, or from the spit, or boiled, / Gris-amber-steamed; all fish from sea or shore, / Freshet, or purling brook, of shell or fin, / And exquisitest name, for which was drained / Pontus and Lucrine bay, and Afric coast [...] / Tall stripling youths rich-clad, of fairer hue / Than Ganymede or Hylas; distant more / Under the trees now tripped, now solemn stood / Nymphs of Diana's train, and Naiades / With fruits and flowers from Amalthea's horn, / And ladies of the Hesperides, that seemed / Fairer than feigned of old, or fabled since / Of fairy damsels
} 
Son's response to this temptation is concise and incisive: "Thy pompous delicacies I contemn, / And count thy specious gifts no gifts but guiles". ${ }^{12}$ The roll call of names does not stop there, for the Son also rehearses a list of kings of Israel and of elsewhere, interspersed with the dangers of ruling without reigning within oneself, with a view to concluding that riches and realms may turn out to be "the toil of fools". ${ }^{13}$

The bewildering enumeration or the chaotic accumulation in those lists, which is their driving force, is typical of the anti-encyclopedic stance. Those lists are not meant for us to find ourselves, but for us to get lost in them. Those lists may also be associated with structure, order, architecture, taxonomy and would present a reality to the measure of human reason - a dreamwork-like, registered vista or tableau vivant, as we see in the way the table is set with all its magnificent foods and fantastical attendants. Barbara Everett remarks on the allusive language shared by the catalogue and the similes Milton uses in Paradise Lost, "A name's virtue is its specificity", and that "Milton's use of names continually converts the denotative into the connotative." ${ }^{14}$ Everett refers not just to the demonic list in the long epic, but to the subsequent roll calls of great names and concludes that the lists in Paradise Lost are devalued or called into doubt by the failure to name anything precisely. Far from agreeing with Everett, I contend that the lists in the short epic are successful especially because they are not naming anything precisely or adequately, thus the Son's apparent immobility in just having to parody some of those lists and curtly shun them shortly after.

met in forest wide / By knights of Logres, or of Lyonnesse, / Lancelot or Pelleas, or Pellenore [...] (MILTON. Paradise Lost and Paradise Regained. Book II, 341-361).

${ }^{12}$ MILTON. Paradise Lost and Paradise Regained. Book II, 390-391.

${ }^{13}$ MILTON. Paradise Lost and Paradise Regained. Book II, 453. The complete list as follows: Gideon and Jephtha, and the shepherd lad [...] / Quintius, Fabricius, Curius, Regulus? [...] / Brings dangers, troubles, cares, and sleepless nights $[\ldots]$ / For therein stands the office of a king, / His honor, virtue, merit and chief praise, / That for the public all this weight he bears. / Yet he who reigns within himself, and rules / Passions, desires, and fears, is more a king [...] (Book II, 439-467).

${ }^{14}$ EVERETT. The End of the Big Names: Milton's Epic Catalogues, p. 262-263. For another discussion of the use of lists in Paradise Lost, SÁ and OLALQUIAGA. Infinity and Voracity of Lists in John Milton's Paradise Lost. 
The lists of confusing effects associated with Satan's temptation, a disoriented exposition, present a reality to the extent of unreason. It is fundamentally anomie, a piece of disorder, a debacle of the intellect. The incompleteness of those lists is what prevents them from taking shape, from reaching final construction. Their cluttered accumulation or their puzzling enumeration always means a supplement and, therefore, a fault or lack, an "inadequation". The Son is quick to dismiss them as "pompous delicacies", "no gifts but guiles" and reproduces a similar baffling list of kings just to conclude that they, detouring from God's ways, produce "the toil of fools".

This "confusional" effect of the lists in the short epic may explain, to some extent, why Erick Gray, in relation to Paradise Lost, argues that "If Milton's imprecise lists make demands upon the reader, we would usually associate with simile [and] it is even more noticeable that his similes take the form of lists." Gray concludes that "The effect of the conflation of the two epic devices [lists and similes] is to undermine them both." ${ }^{15}$ Far from undermining the list as an epic(al) device, I posit that the "confusional" lists in Paradise Regained show the passage of the work towards the text, according to Roland Barthes's terminology, that is, from an organic closed system to an infinite productivity whose closure can only be accidental, not essential. The list, as a category and according to Jack Goody (1979), can always be read as a generalized system of equivalences. The list is a privileged form of what Dennis Hollier (1993) called epistemological charity in that it indiscriminately mixes elements belonging to different orders into a fragmentary and anarchic space. This sense-form represents not only the absence of structure or its disintegration (even when it is united with similes), but it amounts to the flattening of the referential field.

To understand this intrinsic quality of the list, it is necessary to resort to the metaphor of the cyst that nestles in the fabric of the text. Madeleine Jeay (2006) takes up in her definition of the list the notion of heterogeneity (fabric and cyst simultaneously, among other possibilities), which she associates with that of recurrence. Both Philippe Hamon (1993) and Jeay elaborate on the founding work of Jack Goody:

${ }^{15}$ GRAY. Faithful Likenesses: Lists of Similes in Milton, Shelley, and Rossetti, p. 296. 
The list implies discontinuity and not continuity. It presupposes a certain material arrangement, a certain spatial disposition; $[\ldots]$ it has a well-marked beginning and end, a boundary, a border, like a piece of cloth. ${ }^{16}$

The desire or the necessity to collect pieces of the world (in terms of discontinuity and liminality), fragments of moments, accompanied by the attempt to make an im-possible narrative of events, is a mission that has been assigned to literature in general and a mission to which Milton returns with a renewed impetus in the short epic. The lists in Paradise Regained, especially the ones produced by Satan, emerge from the following conditions: the fantasy of chaos remaining an unfulfilled horizon, the complicated coherence among things escaping the worst disorder, and the tortuous cohesive power of analogy barely unifying a worldview by holding the chaos of reality at bay.

"At length collecting all his serpent wiles", ${ }^{17}$ Satan accosts his opponent and rightly summarizes the Son's response to the previous temptation as "All treasures and all gain esteem as dross". ${ }^{18}$ Satan, retorting or murmuring to the following lines of the Son with his deformed and inadequate list associated with glory, ${ }^{19}$ finds again the response of

${ }^{16}$ GOODY. La raison graphique: la domestication de la pensée sauvage, p. 150, my translation. In the original: "La liste implique discontinuité et non continuité. Elle suppose un certain agencement matériel, une certaine disposition spatiale ; elle peut être lue en différents sens, latéralement et verticalement, de haut en bas comme de gauche à droite, ou inversement ; elle a un commencement et une fin bien marquée, une limite, un bord, tout comme une pièce d'étoffe."

${ }^{17}$ MILTON. Paradise Lost and Paradise Regained. Book III, 5.

The complete list as follows: Thy actions to thy words accord, thy words / To thy large heart give utterance due, thy heart / Contains of good, wise, just, the perfect shape. / Should kings and nations from thy mouth consult, / Thy counsel would be as the oracle / Urim and Thummim, those oraculous gems; [...] thy skill, [...] thy prowess, $[\ldots]$ thy few, $[\ldots]$ thy acts, thyself (MILTON. Paradise Lost and Paradise Regained. Book III, 9-24).

${ }^{18}$ MILTON. Paradise Lost and Paradise Regained. Book III, 29.

${ }^{19}$ The complete list as follows: "Think not so slight of glory, therein least / Resembling thy great Father: he seeks glory, / And for his glory all things made, all things / Orders and governs; nor content in Heaven / By all the angels glorified, requires / Glory from men, from all men good or bad, / Wise or unwise, no difference, no exemption; / Above all sacrifice or hallowed gift / Glory he requires, and glory he receives / Promiscuous 
the Son to his rhetorical accumulation to be precise: Satan, "Insatiable of glory had lost all". ${ }^{20}$ Probing all the things best fulfilled in due time, the Son resorts to the list ("Be tried in humble state, and things adverse, / By tribulations, injuries, insults, / Contempts, and scorns, and snares, and violence, / Suffering, abstaining, quietly expecting / Without distrust or doubt, that he may know" $)^{21}$ and concludes that who best can suffer, best can obey. Satan, baffled by the Son's mimicking of his own seemingly coherent excess, can only utter, for the time being, a tautological commonplace: "My error was my error, and my crime /My crime". ${ }^{22}$

Dilating on, multiplying, and reinventing the "exceeding high mountain" where Satan tempts the Son in the very brief accounts of Matthew and Luke, Satan recovers his breath and with a "new train of words" curates an enticing prospect: ${ }^{23}$ places, kingdoms, a multitude of personages from history and romance, in short, a strange and inquisitive parallax. The Son's interpretation of this diabolical panorama defangs excess and accumulation, for he takes up the multiform scene, produces his own contemplative absorption by lexically lengthening on policies ${ }^{24}$

from all nations, Jew or Greek, / Or barbarous, nor exception hath declared; / From us, his foes pronounced, glory he exacts" (MILTON. Paradise Lost and Paradise Regained. Book III, 109-120).

${ }^{20}$ MILTON. Paradise Lost and Paradise Regained. Book III, 148.

${ }^{21}$ MILTON. Paradise Lost and Paradise Regained. Book III, 189-193.

${ }^{22}$ MILTON. Paradise Lost and Paradise Regained. Book III, 212-213.

${ }^{23}$ The complete list as follows: To this high mountain-top the Tempter brought / Our Saviour, and new train of words began: / "Well have we speeded, and o'er hill and dale, / Forest and field, and flood, temples and towers, / Cut shorter many a league [...] / Assyria and her empire's ancient bounds, / Araxes and the Caspian lake, thence on [...]. Against the Scythian, whose incursions wild / Have wasted Sogdiana [...] / He looked and saw what number numberless / The city gates outpoured, light-armed troops [...] / From Arachosia, from Candaor east, / And Margiana to the Hyrcanian cliffs [...] / From Egypt to Euphrates and beyond / Shalt reign, and Rome or Caesar not need fear" (MILTON. Paradise Lost and Paradise Regained. Book III, 265-385).

${ }^{24}$ The complete list as follows: Before mine eyes thou hast set; and in my ear / Vented much policy, and projects deep / Of enemies, of aids, battles and leagues, / Plausible to the world, to me worth nought (MILTON. Paradise Lost and Paradise Regained. Book III, 390-393). 
and finally concludes that, all in all, they are "luggage of war", arguments "Of human weakness rather than of strength."

From the statement of Sève that, paradoxically, the word on a list is cut off from the world and is one with the world (the word becomes a piece of the world), ${ }^{26}$ it is not difficult to see that Satan deforms the pieces of the world on his lists, in terms of the angular difference in direction, and makes those "new" strains of words surpass poetic description by undermining them, the words themselves, in their foundations. Places, kingdoms, multitudes, and later on, buildings and architectural elements are tainted by approximation or by being listed under the aegis of Satan. In Book IV, for example, Satan returns to his "persuasive rhetoric" ${ }^{27}$ and telescopes many guiles into a list of architectural elements, imperial buildings, places, and peoples under Roman yoke. ${ }^{28}$ Exhausted from journeying from place to place and from using his airy microscope to abuse the riches in the "Houses of gods", ${ }^{29}$ Satan is upfront and tells the Son he has "shown thee all / The kingdoms of the world, and all their glory", ${ }^{30}$ so that the tempted Son may "Aim therefore at no less than all the world". ${ }^{31}$ The Son is swift in parodying Satan's feigned magnificence and ironically recalls the devil that to his majestic show he should add:

Their sumptuous gluttonies, and gorgeous feasts

On citron tables or Atlantic stone

(For I have also heard, perhaps have read),

Their wine of Setia, Cales, and Falerne,

${ }^{25}$ MILTON. Paradise Lost and Paradise Regained. Book III, 401-402.

${ }^{26}$ SÈVE. De haut en bas. Philosophies des listes, p. 120.

${ }^{27}$ MILTON. Paradise Lost and Paradise Regained. Book IV, 4

${ }^{28}$ The complete list as follows: With towers and temples proudly elevate / On seven small hills, with palaces adorned, / Porches and theaters, baths, aqueducts, / Statues and trophies, and triumphal arcs, / Gardens and groves presented to his eyes, / Above the highth of mountains interposed: / By what strange parallax or optic skill / Of vision multiplied through air, or glass / Of telescope, were genius to inquire (MILTON. Paradise Lost and Paradise Regained. Book IV, 34-42).

Turrets and terraces, and glittering spires [...] / In various habits on the Appian road [...] / In ample territory, wealth and power (MILTON. Paradise Lost and Paradise Regained. Book IV, 54-82)

${ }^{29}$ MILTON. Paradise Lost and Paradise Regained. Book IV, 56.

${ }^{30}$ MILTON. Paradise Lost and Paradise Regained. Book IV, 88-89.

${ }^{31}$ MILTON. Paradise Lost and Paradise Regained. Book IV, 105. 
Chios and Crete, and how they quaff in gold, Crystal and myrrhine cups embossed with gems And studs of pearl — to me shouldst tell who thirst And hunger still. [... $]^{32}$

The Son's mimetic style does not end in the above list, for his direct message is restated in the following verbal accumulation: "That people, victor once, now vile and base, / Deservedly made vassal; who once just, / Frugal, and mild, and temperate, conquered well, / But govern ill the nations under yoke". 33

Under the will of the Son, the list is an insightful way of restoring the heterogeneity of reality. The world is perceived in a rather discontinuous way: the subjects perceive fragments of reality and struggle to have a global view of existence felt as plural and complex. The Son's lists, by the juxtaposition or rapid sequence of their elements, almost enable the reality of the world and the personal view of the reality of the world to remain together, within the same impression. This use of the list seems to accentuate one of the modes of referential relation, the deixis of the text, by favoring the expression of a divine presence in the world, of a direct, sensitive, and immediate relationship of the subject with reality and, indirectly, with God.

Satan's last attempt to convince the Son he has something to offer him manifests itself in his statement that "All knowledge is not couched in Moses' Law"34 and is elaborated on as a list that embarks on the "Mellifluous streams that watered all the schools / Of Academics old and new". ${ }^{35}$ Before spelling out the names and procedures linked to those academics, Satan invokes the name of places and kings, closely uniting knowledge and power. ${ }^{36}$ The Son's response comes in one succinct list,

\footnotetext{
${ }^{32}$ MILTON. Paradise Lost and Paradise Regained. Book IV, 114-121.

${ }^{33}$ MILTON. Paradise Lost and Paradise Regained. Book IV, 132-135.

${ }^{34}$ MILTON. Paradise Lost and Paradise Regained. Book IV, 225.

${ }^{35}$ MILTON. Paradise Lost and Paradise Regained. Book IV, 277-278.

${ }^{36}$ The complete list as follows: How wilt thou reason with them, how refute / Their idolisms, traditions, paradoxes? [...] / Where on the Aegean shore a city stands / Built nobly, pure the air, and light the soil, / Athens, the eye of Greece, mother of arts [...]/ To Macedon, and Artaxerxes' throne; / To sage philosophy next lend thine ear [...] / Mellifluous streams that watered all the schools / Of Academics old and new, with those / Surnamed Peripatetics, and the sect / Epicurean, and the Stoic severe [...] /
} 
stating that Satan contemns all "Wealth, pleasure, pain or torment, death and life, / Which when he lists". ${ }^{37}$ His next refutal or dismissal of Satan's temptation comes in terms of collecting and gathering: "Deep versed in books and shallow in himself, / Crude or intoxicate, collecting toys / And trifles for choice matters, worth a sponge, / As children gathering pebbles on the shore". ${ }^{38}$ Satan finally recognizes that the Son, after having been followed "on to this waste wild, / Where by all best conjectures I collect / Thou art to be my fatal enemy". 39

Seven more lists are to be found in Book IV and note that the very last one comes from the epic narrator, who seems to follow in the Son's footsteps:

1. Since neither wealth, nor honor, arms, nor arts, / Kingdom nor empire pleases thee; ${ }^{40}$

2. In their conjunction met, give to spell / Sorrows, and labors, opposition, hate, / Attends thee, scorns, reproaches and lastly cruel death, ${ }^{41}$

3. Infernal ghosts, and hellish furies, round / Environed thee; some howled, some yelled, some shrieked, / Some bent at thee their fiery darts; ${ }^{42}$

4. Thy infancy, thy childhood, and thy youth, / Thy manhood last; ${ }^{43}$

5. To understand my adversary, who / And what he is; his wisdom, power, and intent; / By parle, or composition, truce, or league / To win him, or win from him what I can $[\ldots]$ / To try thee, sift

Conjectures, fancies, built on nothing firm. / The first and wisest of them all professed / To know this only, that he nothing knew; / The next to fabling fell and smooth conceits; / A third sort doubted all things, though plain sense; / Others in virtue placed felicity (MILTON. Paradise Lost and Paradise Regained. Book IV, 233-297).

${ }^{37}$ MILTON. Paradise Lost and Paradise Regained. Book IV, 305-306.

${ }^{38}$ MILTON. Paradise Lost and Paradise Regained. Book IV, 327-330.

${ }^{39}$ MILTON. Paradise Lost and Paradise Regained. Book IV, 523-524.

${ }^{40}$ MILTON. Paradise Lost and Paradise Regained. Book IV, 368-369.

${ }^{41}$ MILTON. Paradise Lost and Paradise Regained. Book IV, 385-388.

${ }^{42}$ MILTON. Paradise Lost and Paradise Regained. Book IV, 422-424.

${ }^{43}$ MILTON. Paradise Lost and Paradise Regained. Book IV, 508-509. 
thee, and confess have found thee / Proof against all temptation as a rock; ${ }^{44}$

6. Not more; for honors, riches, kingdoms, glory / Have been before contemned $[\ldots] ;^{45}$

7. And to his crew, that sat consulting, brought / Joyless triumphals of his hoped success, / Ruin, and desperation, and dismay, / Who durst so proudly tempt the Son of God. ${ }^{46}$

Milton intersperses Satan's lists, the Son's parodic lists, and the Son's ultimate pieces of wisdom with unprecedented regularity, and the effect is to turn every reader into a tempted subject, for we must decide how far we are willing to put our faith in any given list before breaking the poetic-scriptural contract. The use of the list in the short epic is a fight against oblivion, against absolute chaos, it partakes in the economy of the full (excessive wordiness and guile, for instance) and the empty (lack of verbose replies, laconic ${ }^{47}$ in style and succinct in correctness, for instance), it denudes and stylizes the quest for elements whose paradoxical importance has been defined above: neither buried in Hell nor wholly retrievable in Heaven. And yet, each element listed, in itself, a fleeting resurrection, a moment otherwise lost. In sum, the lists in the short epic would mark, as a manifestation, the trace, like the shadow, of the intractable fallen world within the very act of worldliness (much like the creation of an alternative Christian ethos, referred to before as "mundanization", and present at the end of the text as an unobserved return home to the mother's house), always leaving a space of nothingness necessarily paradoxical and in some ways astonishingly so. The lists, thus, in their expansions and at their widest levels, always resonate with a power that accentuates the trace or the language of that which was/is irretrievably lost, henceforth always foreign and forever undecidable, like an otherworldly song sung on a field of steles.

\footnotetext{
${ }^{44}$ MILTON. Paradise Lost and Paradise Regained. Book IV, 527-533.

${ }^{45}$ MILTON. Paradise Lost and Paradise Regained. Book IV, 536-537.

${ }^{46}$ MILTON. Paradise Lost and Paradise Regained. Book IV, 577-580.

${ }^{47}$ Etymologically, the word started being used in the middle of the 16th century (in the sense "Laconian"): via Latin from Greek Lakōnikos, from Lakōn "Laconia, Sparta", the Spartans being known for their terse speech. Ironically, the Son's responses are informed by Greek, if not wisdom, style, after all.
} 
Aletria, Belo Horizonte, v. 29, n. 4, p. 113-128, 2019

\section{References}

CAVE, Terence C. The Cornucopian Text: Problems of Writing in the French Renaissance. Oxford: Clarendon, 1979.

ECO, Umberto. The Infinity of Lists. London: MacLehose, 2009.

EVERETT, Barbara. The End of the Big Names: Milton's Epic Catalogues. In: CAREY, John (ed.). English Renaissance Studies: Presented to Dame Helen Gardner. Oxford: Clarendon Press, 1980. p. 254-270.

GOODY, Jack. La raison graphique: la domestication de la pensée sauvage. Paris: Édition de Minuit, 1979.

GRAY, Erik. Faithful Likenesses: Lists of Similes. In: MILTON, SHELLEY, ROSSETTI. Texas Studies in Literature and Language, Austin, v. 48, n. 4, p. 291-311, 2006. DOI: https://doi.org/10.1353/ ts1.2007.0001.

HALPERN, Richard. The Poetics of Primitive Accumulation: English Renaissance Culture and the Genealogy of Capital. London: Cornell University Press, 1991.

HAMON, Philippe. Du descriptif. Paris: Hachette, 1993.

HOLLIER, Denis. Les dépossédés (Bataille, Caillois, Leiris, Malraux, Sartre). Paris: Éditions de Minuit, 1993.

JEAY, Madeleine. Le commerce des mots: l'usage des listes dans la littérature médiévale (XIIe-XVe siècles). Geneva: Droz, 2006.

KNIGHT, Jeffrey Todd. Bound to Read: Compilations, Collections, and the Making of Renaissance Literature. Philadelphia: University of Pennsylvania Press, 2013.

KNOPPERS, Laura Lunger. Paradise Regained and the Politics of Martyrdom. Modern Philology, Chicago, v. 90, n. 2, p. 200-219, 1992. DOI: https://doi.org/10.1086/392056.

MILCENT-LAWSON, Sophie, LECOLLE, Michelle and MICHEL, Raymond. Liste et effet liste en littérature. Paris: Classiques Garnier, 2013.

MILTON, John. 1608-1674./ Paradise Lost and Paradise Regained. New York: Signet Classic, 2001. 
SÁ, Luiz Fernando Ferreira; OLALQUIAGA, Mayra Helena Alves. Infinity and Voracity of Lists in John Milton's Paradise Lost. Aletria: Revista de Estudos de Literatura, Belo Horizonte, v. 25, p. 97-112, 2015. SÈVE, Bernard. De haut en bas: philosophie des listes. Paris: Éditions du Seuil, 2010.

Recebido em: 8 de junho de 2019. Aprovado em: 9 de setembro de 2019. 